\title{
BETWEEN ISTANBUL AND VENICE AGENCY, FAITH, AND EMPIRE IN THE SIXTEENTH CENTURY
}

\author{
JOHN JEFFRIES MARTIN \\ DUKE UNIVERSITY
}

\begin{abstract}
$\boldsymbol{\varphi}$
In 1598 Lazaro Soranzo's L'Ottomano, a book that would become something of an early modern bestseller, was published in Ferrara, with French, German, English, and Latin translations following on almost immediately. ${ }^{1}$ Such success was not in itself surprising. Works reporting on the institutions, customs, and beliefs of other parts of the world had become increasingly fashionable in sixteenthcentury Europe; and interest in the Ottoman Empire was widespread. But until the British historian Noel Malcolm produced his masterful Agents of Empire: Knights, Corsairs, Jesuits and Spies in the Sixteenth-Century Mediterranean World, no one had taken the time to investigate Soranzo's tantalizing allusion to one of his sources: Del Bellerbegato della Romania [On the Beylerbeylik of Rumeli]. ${ }^{2}$ Since its author, a certain Antonio Bruni, was obscure, and the text had never been published, finding it was no easy task. Eventually Malcolm located two manuscript copies: one in the Vatican Library, the other in the Library of the Museo Correr in Venice. What he discovered was a short text that offered a rich ethnographic description of early modern Albania along with a report on its religious divisions and military assets. And this unknown text raised an important puzzle about the identity of its virtually unknown author, Antonio Bruni, who seemed so well informed about many aspects of the Ottoman world. As Malcolm probed further into a wide array of archival and printed sources, he began assembling all the clues he could find about Bruni and his family. Quite suddenly, as he writes, he 'realized that [he] had a much larger project on his hands'.
\end{abstract}

Lazzaro Soranzo, L'Ottomano, Ferrara: Vittorio Baldini, 1598.

Noel Malcolm, Agents of Empire: Knights, Corsairs, Jesuits and Spies in the Sixteenth-Century Mediterranean World, Oxford: Oxford University Press, 2015. 
Few historians would have been prepared as Malcolm to reconstruct the history of either this author or of early sixteenth-century Albania, much less the wider Mediterranean world of this period. While well known for his studies and editions of Thomas Hobbes-the subject of his Ph.D. thesis at CambridgeMalcolm has also had a long-standing interest in the history of the Balkans. In 1984 he published De Dominis (1560-1624): Venetian, Anglican, Ecumenist and Relapsed Heretic, a short but fascinating study of this Dalmatian bishop whose De republica ecclesiastica was one of the more important works of political theory in the early seventeenth century. Then from the late 1980s to the mid-1990s Malcolm worked as a journalist, first for The Spectator and later for The Daily Telegraph, devoting much of his attentions to the Balkans. He has written two important books on the history of the region: Bosnia: A Short History (1994) and Kosovo: A Short History (1998). In these volumes, he pushed back against traditional interpretations that viewed the violence in these regions as expressions of long-standing racial animosities. He found a much more diverse population; he had a deep sense of the complexity of these cultures. And he infuriated some Serb nationalists in his deconstruction of the myth of the Battle of Kosovo on the Field of Blackbirds of 1389. ${ }^{3}$ Finally, Malcolm's command of languages is legendary. Students of his works on Hobbes, for example, will recognize him as a superb Latinist, with a command of all the major western European languages. ${ }^{4}$ But he also reads Albanian, Bosnian, Modern Greek, Macedonian, Polish, Romanian, SerboCroatian, and Turkish-and this is by no means a complete list. It is fortunate that a scholar this gifted has been able, after 'retiring' from journalism in 1995, to enjoy considerable support for his research and writings. Since 2002 he has been Senior Research Fellow at All Souls, Oxford.

What Malcolm's knowledge of the Balkans and their languages offered him was the ability to examine the history of the Venetian and Ottoman empires not from the perspective of Venice and Istanbul but rather from one of the major borderlands that lay between these two states: in this case, from Venetian Albania. This thin strip of territory reaching from Ulcinj (Dulcigno) to Kotor (Cattaro) on the eastern shore of the Adriatic is among the most beautiful coastlines in the world. In the sixteenth century this region was home to only four small cities or towns. Ulcinj had a population of about 1600 souls; Bar some

3 Aleksa Djilas, 'Imaging Kosovo: A Biased Western Accounts Fans Confusion', Foreign Affairs 77 (1998), pp. 124-131 and Malcolm's response 'What Ancient Hatreds?', Foreign Affairs 78 (1999), pp. $130-134$.

4 In addition to his important collection of studies on Hobbes-Malcolm, Aspects of Hobbes (2002)Malcolm has edited The Correspondence of Thomas Hobbes (1994) and, most recently, Hobbes' Leviathan in an award-winning three volume edition, the first to include both the English and Latin versions of the text (2012). 
2500 residents; Budva a mere 800; and Kotor perhaps three to four thousand. These towns and their hinterlands were important to Venice for their agricultural resources. They also constituted an important defensive barrier against the projection of Ottoman power into the Adriatic. As is well known the Ottoman Turks had made significant inroads into the Balkans even before their conquest of Constantinople in 1453. It was in the period 1415 to 1423 that they first imposed their rule in much of Albania, though not without resistance. Gjergi Kastriota called 'Skanderbeg' led a series of major rebellions against the Ottomans in the middle decades of the fifteenth century, but by the end the century the Ottomans had consolidated their power in all of Albania apart from the coastal strip that remained under Venetian rule.

Malcolm focuses in particular on two families: the Bruni and the Bruti. Both were Albanian. The Bruni had been a patrician family in Shkodër (Scutari). In 1479, when this town fell to the Ottomans, they fled to Ulcinj where they were able to establish themselves as leading figures in this small city. The Bruti, originally from Durrës (Durazzo) and Lezhë (Alessio)-like the Bruni under pressure from the Ottomans-arrived in Ulcinj a bit later, in the early sixteenth century. There they married into the Bruni family; and, in certain respects, the destinies of these two clans would be tied together over much of the rest of the century. But what renders these families of particular interest to Malcolm is that, as members of the local elite, the Bruni and the Bruti were bilingual, moving easily between the Italian and Albanian languages. As Malcolm notes, 'the Brunis and the Brutis were genuine linguistic and cultural amphibians. And that, as we shall see, was essential to their success in the wider Mediterranean world.'

The first part of the book, which traces the fortunes of these two families in the quarter century prior to Lepanto focuses in particular on Antonio Bruti, who served Venice as an intelligencer and an emissary in its relations with the Ottoman Empire; Giovanni Bruni, who became Archbishop of Bar in 1551 and eventually a delegate to the Council of Trent; and Gasparo Bruni, Giovanni's brother, who became a Knight of Malta. Collectively these figures make it clear how this polyglot elite managed to find much favor from the Venetians and the papacy. By the 1560s it must have seemed as though they would continue to prosper in Ulcinj.

Yet this generation was devastated by the War of Cyprus. As part of this conflict, Ottoman forces seized Ulcinj and Bar in 1571. At Ulcinj, the conquest was brutal. A contemporary report from Kotor reported, "when the general of the land army [Ahmed Pasha] entered the city, he made his men cut to pieces all those who had remained and set fire to some houses which were full of women and children'. When Bar fell shortly afterwards, Giovanni Bruni, the archbishop, was taken captive. Both the Bruni and Bruti families once again saw their lives 
destroyed by Ottoman forces; and their survivors would emigrate to safer territories: this time to the Istrian port of Koper (Capodistria), better protected by the Venetian state.

It was, however, the experience of the Bruni in the Battle of Lepanto that underscored the vulnerability of even these prosperous families to the wages of warfare. As Ottoman power increasingly seemed to threaten not only Venetian control of Cyprus but also Spanish interest in north Africa, the western powers under the leadership of Pope Pius V forged a Holy League to fight the Turks to save Cyprus. Both the Ottomans and the Holy League prepared above all for a major battle at sea. It came on 7 October 1571 in the Gulf of Patras. Malcolm's description of this battle is powerful. He is particularly effective in making it clear that galley warfare in the sixteenth century had not yet become a contest of cannon volleys but remained very much a platform for virtual hand-to-hand combat as ship captains attempted to manoeuver in such a way that their soldiers could board an enemy's vessel and then seek to subdue them, fighting to the death. In such a context naval warfare took on an intimate and brutal quality. But Lepanto also became a tragedy for the Bruni. Giovanni Bruni, Archbishop of Barwho, as we have seen, had been taken captive in 1571-and his nephew Nicolò were now serving as galley slaves aboard an Ottoman ship, in all likelihood the ship of the commander of the Ottoman fleet. His brother Gasparo meanwhile was in the lead ship of the Holy League. In the crazed aftermath of the battle, Spanish soldiers, disbelieving their claims that they were Christians, killed both Giovanni Bruni and his nephew. As Malcolm points out, at the time of their slaughter, Giovanni's brother Gasparo may have been less than 100 yards away.

Yet, even after this devastation and now based in Koper, both families continued to thrive in the interstices of the Ottoman and Christian worlds. Gasparo Bruni, commended for his bravery at Lepanto, found papal favor and received an important military post in Avignon where he would fight to protect Catholic interests in the midst of the French Wars of Religion. But it is Malcolm's narrative of the career of Bartolomeo Bruti that is most gripping. Bartolomeo, Antonio's son, had sought a position as a giovane di lingua in Istanbul in 1575 . He received the position but was dismissed from it shortly thereafter. Evidently he was a lazy student, but he nonetheless found favor at court and shortly came to play a major role in brokering a prisoner exchange between the Ottomans and Madrid. In this role he soon found himself entering into a multi-layered role of espionage and counter-espionage. And Malcolm's portrayal of the role of spies in a sea hungry for information is one of the richest veins of this book. We learn, for example, that Hürrem Bey, the Sultan's chief dragoman, was 'on the Venetian payroll' and 'also working secretly for Spain'. Identities in this world were multiple. And Bartolomeo's multiple identities and his ability to serve as a gobetween paid off. After helping forge a truce between Madrid and Istanbul, he 
found favor with some of the leading viziers and he was offered a position as a commander of Ottoman forces in Moldavia. ${ }^{5}$ There, as the Long War between the Habsburgs and Spain heated up in the 1590s, he found himself in increasingly treacherous waters. In 1592, falling afoul of the voivod of Moldavia, he was captured. His nose was lopped off and he was strangled.

Agents of Empire is an engrossing narrative. And, as its subtitle makes clear, it is also pitched to a broad readership. As popular history it has much to commend. Malcolm's sustained focus on several prominent figures-with particular attention to the lives and careers of Gasparo Bruni and Bartolomeo Bruti-eases the reading and makes it possible to follow the story without difficulty. The writing style is robust and clear; and the author is especially effective in moving back and forth between moments of high drama (Lepanto; the prisoner exchange at Dubrovnik; the execution of Bartolomeo Bruti) and textbook like presentations of background material that helps make sense of this forgotten Mediterranean world. Some specialist may find the overviews of the ransoming of captives or of the naval battles familiar but most will find the discussions of the giovani di lingua and the information networks fresh. But this is no ordinary popular history. To the contrary, it is the product of an indefatigable scholar who tells here an unknown story based almost exclusively on archival documents. To write this book Malcolm consulted primary materials in Austria, Croatia, England, France, Italy, Poland, Slovenia, Spain, and Vatican City. It was his research in archives and libraries throughout Europe that enabled him to reconstruct the lives of the Bruni and Bruti, now figures who have the opportunity to become as familiar to historians of early modern Europe as Emmanuel Le Roy Ladurie's Thomas Platter and his sons. ${ }^{6}$ In short, Malcolm has brought to light individuals whose experiences-intrinsically interesting-make it possible to think through the past in new and fruitful ways. But what about the book's substantive contributions?

The very title of the book signals perhaps Malcolm's most important intervention. Malcolm's approach lays remarkable stress on the agency of certain individuals-almost always wealthy men-in the making of empire. And certainly within the framework of a narrative deliberately structured around a collective biography of two families the author's emphasis on agency seems compelling, at least at first. Yet, as in any historical study of significance, the very frame that succeeds in highlighting certain aspects of the past occludes others. To be concise, what is lost in this book is a sense of the role that the environment, of

5 On this episode, see also Fernand Braudel, The Mediterranean and the Mediterranean World in the Age of Philip II, trans. Siân Reynolds, 2 vols, New York-London: Harper \& Row-Collins, 1972, vol. II, pp. 1151-1159. Here Braudel gives 'Aurelio' as Bruti's first name, but it is the same individual.

6 Emmanuel Le Roy Ladurie, The Beggar and the Professor: A Sixteenth-Century Family Saga, trans. Arthur Goldhammer, Chicago: University of Chicago Press, 1997. 
economic trends, and of shifts in social structures in shaping the history of the Mediterranean in this period.

The omission is especially conspicuous because it was Fernand Braudel, one of the master historians of the twentieth century, whose study The Mediterranean and the Mediterranean World, first published in 1949, made a powerful case for role of the environment and socio-economic trends in setting the parameters of the possible in the political and military history of a period. Yet, about these deeper structures that Braudel viewed as essential for the understanding of history we learn very little and the result is that the springboards for the agency of the Bruni and the Bruti, as well as many other individuals who dominate the pages of this book, appear to be their personalities and their resourcefulness. Both Chapter 3 on Antonio Bruti and Chapter 11 on Bartoloemo Bruti, for example, open with their sending petitions the government of Venice-perhaps a rhetorical device but one that invests them with the qualities of prime movers. And there are many other such examples of personality trumping structure in the book. A 'hot-headed' Venetian naval commander sank two Ottoman ships and precipitated a war between empires. In the end, though, Malcolm frequently balances personal against larger forces: his discussion of the learned and compassionate Moldavian prince Petru Șchiopul's motives, for example, is multifaceted, with a full recognition of the various political and cultural pressures on a ruler.

This is not to say that Malcolm invests everyone with agency. He is, after all, writing primarily about provincial elites. And he recognizes that there were tens of thousands of souls in the Mediterranean who were not so fortunate. Some of his most moving passages give an account of the large numbers of individualsmen, women, and children; Muslim and Christian; young and old-who were sold into slavery and whose status stripped them of almost all their agency, though some of the more well-connected of these captives did manage to find their way back to their home countries through the elaborate system of ransoming that functioned as a kind of black market in human lives in the early modern Mediterranean.

Malcolm also suggests the need to rethink the role of religion in this period. Religion has always been a major feature of the history of the Mediterranean. ${ }^{7}$ And no book on the history of this sea in the early modern period can escape the importance of Jews, Muslims, and Christians in the making of the history of this period. On this front, Malcolm's study casts new light on the history of the Counter Reformation by placing this Catholic offensive in the context of the difficult political history of this period. Through the study of both Giovanni

John Jeffries Martin, 'Crossing Religious Boundaries in the Medieval and Early Modern Mediterranean', Journal of Medieval and Early Modern Studies 41 (2011), pp. 459-462. 
Bruni, who became Archbishop of Bar in 1551 and later served as a delegate to the Council of Trent, and Gasparo Bruni, a Knight of Malta who spent the final years of his career in service to the papacy as a military commander in the papal enclave of Avignon during the French Wars of Religion, Malcolm offers readers a richly textured portrait not of a purely spiritual movement as is often the case in histories of the Counter Reformation but rather of a spiritual movement that was deeply intertwined with political and military interests of the day.

But does Malcolm underplay the force of religious beliefs? Certainly, at this granular level, Malcolm's general observations about the limited role of religion in the lives of individuals who were often caught between the West and the Ottoman worlds carries conviction. But his larger generalizations about the role of relative weight to which Christian and Ottoman authorities gave to religion in their attitudes towards their enemies is less convincing. He is quite right to insist that the Ottoman policy in both the War of Cyprus and the Long War-the two major conflicts at the center of his study-was shaped less by religious zeal than by geo-political and strategic considerations. But the closing argument in his book that the Counter Reformation shaped a far more zealous politics in western Europe, one in which a crusading mentality played a dominant role in shaping Christian attitudes towards Islam, while offering a potentially intriguing contrast to the more pragmatic Ottomans, seems tacked on, and Malcolm's evidence here hangs tenuously on the views of Popes Pius V, proponent of the Holy League, and Clement VIII, propagandist for the Hapsburgs during the Long War. I do not doubt that both these papal courts underscored the religious battle that lay before them nor that such attitudes can't be found elsewhere. But I am by no means convinced that the Venetians or the Spanish or the French viewed matters in this light.

In the end, however, it is this book's contribution to our evolving understanding of empire that Malcolm makes his most important contribution. In recent decades empire has emerged as a major theme in historical studies. There are many reasons for this. By the end of the twentieth century the nation state, which had seemed a promising model for the political organization of the world in the nineteenth century, appeared too often to be an incubator of conflict and warfare. At the same time a growing emphasis on world history among scholars has recognized that imperial systems played a major role in the shaping of global connections. And aspects of empires-their capaciousness, the diversity of their subject populations, even their relative tolerance-render them most interesting to think with. Certainly in my own subfield of Venetian history, this shift has been palpable. Forty years ago most historians of Venice focused on the city of Venice itself, but a newer generation of scholars-Bernard Doumerc, 
John Jeffries Martin

Eric Durstler, Monique O'Connell, and Natalie Rothman, among others-have now begun to shift the focus to various aspects of Venice as an imperial power. ${ }^{8}$

The new imperial histories of Venice are benefitting too from the general trend to view empires not in light of the old colonial model-with a central power imposing its will on its subject territories-but rather as far more complex system of territories connected to the imperial center on the basis of diverse and at times mutual interests. Thus historians of empire attend not merely to its metropole but also to its peripheries, its borderlands, and reveal a far more diverse, polycentric system. Malcolm explicitly presents both the Venetian and the Ottoman Empire in this light. He does so as well with a clear understanding that the Mediterranean itself was a shifting mosaic of diverse faiths and customs; and that, whatever the political systems that various dynasties or elites tried to erect there, many men and women-rich and poor-moved through this sea and its surrounding territories with relative ease. Borders were imagined but easily crossed or at least crossed without much difficulty. As Peregrine Horden and Nicolas Purcell have shown in their magisterial The Corrupting Sea: A Study of Mediterranean History (2000) the Mediterranean itself was 'a mediator and a boundary', and other more specialized scholarship has made a similar contribution. In the case of Venice two historians in particularly have played an especially important role in demonstrating the porosity of borders between the Serenissima and the Ottoman Empire. Through her years of meticulous study in the Venetian archives Maria Pia Pedani has uncovered a myriad of interconnections between Ottoman and Venetian families in the early modern period, but it is Natalie Rothman's Brokered Empires: Tran-Imperial Subjects between Venice and Istanbul (2012) that has done the most to recast our understanding of the complex and paradoxical ways these two empires intersected. ${ }^{9}$ In particular, her conceptualization of the trans-imperial subject is extremely fruitful, making it possible, as she notes in her Introduction 'to understand the perspective of those who were caught in the web of complex imperial mechanisms but who at the same time were essential to producing the means to calibrate, classify, and demarcate imperial identities. ${ }^{10}$

8 Bernard Doumerc, Venise et son empire en Méditeranée, IXe-XVe siècle, Paris: Ellipses, 2012; Eric R. Durstler, Venetians in Constantinople: Nation, Identity, and Coexistence in the Early Modern Mediterranean, Baltimore-London: Johns Hopkins University Press, 2006; Monique O'Connell, Men of Empire: Power and Negotiation in Venice's Maritime State, Baltimore-London: Johns Hopkins University Press, 2009; and Natalie Rothman, Brokering Empire: Trans-Imperial Subjects Between Venice and Istanbul, Ithaca: Cornell University Press, 2012.

9 Maria Pia Pedani, In nome del Gran Signore: inviati ottomani a Venezia dalla caduta di Costantinopoli alla Guerra di Candia, Venice: Deputazione di storia patria per le Venezie, 1994; and Ead., Dalla frontiera al confine Rome-Venice: Herder-Università Ca' Foscari, 2002.

10 Rothamn, Brokering Empire, p. 13. 
While Malcolm's approach is decidedly non-theoretical, it builds upon these shifting notions of empire and, in its detail, offers rich perspectives on the Ottoman and Venetian worlds in this period. Perhaps his most significant contribution is the degree to which he is able to offer a sense of the diverse ways in which his trans-imperial subjects-the Bruti and the Bruni of the Albanian borderlands-were caught up in the service of the Ottoman Empire and their service to Venice, Rome, and Madrid. In both cases, patronage and familial connections were extremely powerful in shaping the destinies of such figures as Bartolomeo Bruti and Gasparo Bruni. In western Christendom, both families developed their connections through a variety of strategies-among which was the choice of the right school such as the Jesuit College in Rome to which Gasparo Bruni sent his son Antonio, the author of the Del Bellerbegato della Romania. The decision to dispatch a son off to Istanbul to learn Ottoman Turkish-path pursued both by Bartolomeo and Cristoforo Bruti-offered individuals from the empire's peripheries opportunities for advancement at the highest levels of Ottoman society. The mastery of multiple, diverse languages was a valuable commodity in this polyglot world. Certainly Malcolm's Bruni and the Bruti are excellent exemplars of Rothman's imperial subjects; and, indeed more serious readers will benefit from studying Rothman's book in tandem with Malcolm's.

A major contribution of Agents of Empire is to a broader understanding of the Mediterranean. This sea, then as now, was a space of conflict as well as constructive interaction among the diverse cultures-European, Asian, and African-which shared its shores. Yet this book, along with several of Malcolm's other projects, hints at a larger canvas upon which it may be possible to deepen our understanding of the interplay of Ottoman and western European societies and cultures, and indeed of Islamic and Christian cultures in the early modern world.

In an insightful article on Tommaso Campanella-originally presented as the Elie Kedourie Memorial Lecture to the British Academy in 2003-Malcolm drew attention to the influence of early modern understandings of Ottoman society in shaping both Campanella's Monarchia di Spagna and his ideal of a utopian society in his Città del Sole. ${ }^{11}$ And in a more recent, highly detailed article on the first English translation of the Qu'ran, Malcolm makes a similar point but casts it even more broadly:

Ordinary readers throughout Europe could be interested in Islam for a range of reasons, political as well as religious. The Ottoman Empire was a major power; it and its satellites impinged directly, through warfare and piracy, on the Holy

11 Noel Malcolm, 'The Crescent and the City of the Sun: Islam and the Renaissance Utopia of Tommaso Campanella', Proceedings of the British Academy 125 (2004), pp. 41-67. 
Roman Empire and all the Christian states of the Mediterranean region. England was less directly affected by such activities, though its mariners were taken captive in the Mediterranean, and Muslim pirates and corsairs did raid English waters and the coastlines of Ireland and the wet of England. But travel, trade, and a general interest in the politics and history of Europe were quite sufficient to create an appetite for information about the Ottoman and Islamic world, to which the frequent reprintings of works such as Knolles's Ottoman history and [George] Sandys's travelogue bear witness. ${ }^{12}$

Of course, Malcolm's interest in bridges between these worlds goes back a long way. As we have seen, Malcolm's first book was a study of a renegade Dalmatian bishop who spent several years in England. And his early interest in George Sandys's travelogue is more than matched by his studies of George's brother, Edwin Sandys, a founding investor in the Virginia Company, who worked closely with Thomas Hobbes. ${ }^{13}$

These bridges are promising. Malcolm's own accomplishments in two distinct fields-early modern British political theory and the history of the Balkans-have led some to suspect that there is not one but rather two Noel Malcolm's impersonating a single individual. But such frivolous speculations are only possible because of the bifurcated historiographies of Europe: one focused on the West, another on the East. The reality, of course, is that Malcolm is a unicum, whose tireless forays over the course of his career, have brought to light a number of threads that make it plain that Europe too-not the imagined political unity of Europe but rather a Europe constructed of lived exchanges that reached from Istanbul to London-was a less divided continent that previous generations of historians imagined. Ultimately Agents of Empire is a contribution to our rethinking of Europe and the complex interplay of ideas, representations, economic interests, diverse religions, and political structures over the longue durée.

12 Noel Malcolm, 'The 1649 English Translation of the Koran: Its Origins and Significance', Journal of the Courtauld and Warburg Institutes 75 (2012), pp. 288-299.

13 Noel Malcolm, 'Hobbes, Sandys, and the Virginia Company', The Historical Journal 24 (1981), pp. 297-321, repr. in Id., Aspects of Hobbes, Oxford: Oxford University Press, 2002, pp. 53-79. 